УДК 339.5, 339.9

DOI: https://doi.org/10.32782/2520-2200/2018-6-10

Ternopil Ivan Puluj National Technical University

Крамар I.Ю.

кандидат економічних наук, доцент, доцент кафедри економіки та фрінансів

Тернопільського національного технічного університету імені Івана Пулюя

Marynenko Nataliia

Ternopil Ivan Puluj National Technical University

Мариненко Н.Ю.

доктор економічних наук, професор, професор кафедри економіки та фрінансів Тернопільського національного технічного університету імені Івана Пулюя

Podvirna Tetiana

Ternopil Ivan Puluj National Technical University

Подвірна Т.В. кандидат економічних наук, старший викладач кафедри економіки та фрінансів Тернопільського національного технічного університету імені Івана Пулюя

\title{
STRATEGIC PROGRAMS OF INTERNATIONAL COOPERATION OF THE WESTERN REGION OF UKRAINE FOR 2018-2020
}

\section{СТРАТЕГІЧНІ ПРОГРАМИ МІЖНАРОДНОГО СПІВРОБІТНИЦТВА ЗАХІДНОГО РЕГІОНУ УКРАЇНИ НА 2018-2020 РОКИ}

The content of the Regional Programs of International Cooperation of the Western Region of Ukraine for 2018-2020 is disclosed in the article on the example of three regions: Lviv, Ternopil and Ivano-Frankivsk. It is determined that the main problems that exist in the region are as following: the lack of measures specification for the development of interregional cooperation within the framework of existed agreements, insufficient level of interregional cooperation development in the field of economy, in particular in terms of attracting investments and the necessity of infrastructure development. In order to solve those problems, main tasks of the Regional Programs, which are common to the three regions, as well as those that are individual for each region in particular, are identified. Positive expectations from the realization of the specified tasks with the purpose of international cooperation development of the region are characterized.

Keywords: international cooperation, European integration, investment attractiveness of the region, cross-border cooperation.

У статті розкрито зміст регіональних програм міжнародного співробітництва Західного регіону України на 2018-2020 рр. на прикладі трьох областей: Львівської, Тернопільської та Івано-Франківської. Подано коротку характеристику кожної з програм за такими параметрами: розробник, строки виконання, фрінансування заходів, звітність, очікувана ефективність виконання. Визначено, що основними проблемами, які існують в регіоні, $є$ недостатня конкретизація заходів щодо розвитку міжрегіонального співробітництва в рамках угод, недостатній рівень розвитку міжрегіонального співробітництва у сфері економіки, зокрема в частині залучення інвестицій, та потреба у розвитку інфраструктури. Для вирішення цих проблем виділено основні завдання регіональних програм, які є спільними для трьох областей, а також ті, котрі $є$ індивідуальними, зважаючи на особливості розвитку та нагальні проблеми області. Встановлено, що особливої уваги Регіональна програма міжнародного співробітництва Львівської області надає співфінансуванню проектів, що 
реалізуються із залученням міжнародної технічної допомоги, розробленню заходів щодо промоції області на міжнародних ринках, установленню нових та реалізації наявних зв'язків із міжнародними організаціями та іноземними партнерами. Водночас основний акцент Програми Тернопільської області зроблено на залучення інвестицій у регіон та розширення ринків збуту підприємств, розташованих на його території. Досліджено, що Програма для Івано-Франківської області передбачає також популяризацію досягнень області в економічній, культурній, туристичній сферах для забезпечення позитивного іміджу регіону. У статті охарактеризовано позитивні очікування від реалізації вказаних завдань для розвитку міжнародного співробітництва регіону.

Ключові слова: міжнародне співробітництво, європейська інтеграція, інвестиційна привабливість регіону, транскордонне співробітництво.

В статье раскрыто содержание региональных программ международного сотрудничества Западного региона Украины на 2018-2020 гг. на примере трех областей: Львовской, Тернопольской и Ивано-Франковской. Определено, что основными проблемами, которые существуют в регионе, являются недостаточная конкретизация мер по развитию межрегионального сотрудничества в рамках соглашений, недостаточный уровень развития межрегионального сотрудничества в сфере экономики, в частности в части привлечения инвестиций, и потребность в развитии инфраструктуры. Для решения проблем выделены основные задачи региональных программ, которые являются общими для трех областей, а также те, которые являются индивидуальными, учитывая особенности развития области. Охарактеризованы положительные ожидания от реализации указанных задач для развития международного сотрудничества региона.

Ключевые слова: международное сотрудничество, европейская интеграция, инвестиционная привлекательность региона, трансграничное сотрудничество.

Formulation of the problem. International cooperation plays an important role in the socio-economic development of Ukraine as a whole and in the Western region in particular. One of the main priorities of the expansion of interregional cooperation and integration of Ukraine into the world economic space is the development and implementation of a coherent and balanced foreign economic policy aimed at increasing the competitiveness and investment attractiveness of the region's economy, forming a positive international image, and using the best foreign experience, capabilities and resources, including through the implementation of joint projects.

In this regard, it is relevant to study the peculiarities of international cooperation of the regions, in particular, in the part of foreign economic cooperation, which is a special type of economic activity and is closely related with the whole economic complex of the region. In addition, it is specifically the foreign economic activity, which attracts investments and obtains international technical assistance. This allows to solve a number of problematic issues, for example, the lack of energy carriers, new machines and equipment, technologies, and some consumer goods.

Analysis of recent research and publications. Among Ukrainian researchers who studied the issues of international cooperation at various times, were M. Buromensky, O. Grinenko, O. Kyievets, T. Syroid, L. Timchenko and others who made a significant contribution the solution of researched problems. The study of cross-border cooperation was conducted by V. Budkin, L. Kistersky, P. Lutsyshyn, N. Mikula, A. Moky,
A. Perederiy, S. Pysarenko, A. Topciyev, O. Chmir and others; the role of regions in the formation of world trade and economic relations is the topic of research in modern scientific works of such scholars as B. Gubsky, D. Lukyanenko, Y. Makogon, S. Nalyvaichenko, V. Reutov. In addition, the outlined issues were researched by such foreign scholars as G. Boas, M. Virali, R. Wolfrum, M. Shaw, G. Shermers, J. Foer and others. In the part of international cooperation of municipalities the issue was investigated by such foreign researchers as F. Angelent, E. Wismans M. Hillynus G. Y. N. Shep.

The purpose of the article is to research the main aspects of Regional Programs for International Cooperation of Lviv, Ternopil and Ivano-Frankivsk regions for 2018-2020 in terms of identifying main problems that exist in this area and ways of their solution.

Presentation of the main research material. The western region of Ukraine includes eight regions: Volyn, Zakarpattya, Ivano-Frankivsk, Lviv, Rivne, Ternopil, Khmelnytsky and Chernivtsi. However, most often the term "Western Ukraine" denotes only three of these areas, namely: Lviv, Ivano-Frankivsk, and Ternopil regions. Therefore, the analysis of the main directions of international cooperation will be carried out precisely in these three regions of Western Ukraine.

The Decree of the President of Ukraine dated January 12, 2015, No. 5/2015, approved the Strategy for Sustainable Development "Ukraine-2020", which stipulates implementation of Ukraine development programs within the framework of strategy four vectors, in particular: development 
of Ukrainian exports, investments attraction, popularization of Ukraine within the world and advancement of Ukraine's interests in the global information space. This strategy became the basis for the Regional Programs, the analysis of which is given below.

Each of the regions of the Western Ukraine, in accordance with Article 143 of the Constitution of Ukraine and paragraph 1 of Article 43, paragraph 1 of the Law of Ukraine "On Local Self-Government in Ukraine", as well as with the aim of implementing the policy of international and cross-border cooperation, attraction of international technical assistance and international promotion, has approved Regional Programs for International Cooperation for 2018-2020 years. Therefore, the analysis of the directions of international cooperation is carried out on the basis of such regional programs of each of the specified areas.
Each of the Regional Programs includes description of its purpose, objectives of the program, identifying the problems to be addressed, ways of their solution and steps that need to be taken to achieve the objectives.

Main characteristics of the Regional Programs for International Cooperation of Lviv, Ternopil and Ivano-Frankivsk regions are presented in Table 1.

From the information provided in the Table 1, it is clear that expectations of the Regional Programs for International Cooperation implementation for all three regions are significant. That is why the actual fulfilment of the tasks that Programs themself envisages is important. First of all, it is necessary to identify the problems that exist today in the researched regions and can be grouped into the following:

- insufficient specification of measures to develop interregional cooperation within the framework of agreements;

Brief description of the Regional Programs of International Cooperation of Lviv, Ternopil and Ivano-Frankivsk regions

\begin{tabular}{|c|c|c|c|c|}
\hline \multirow{2}{*}{ № } & \multirow{2}{*}{ Indicator } & \multicolumn{3}{|c|}{ Characteristics in each region } \\
\hline & & Lviv & \begin{tabular}{|c|} 
Ternopil \\
\end{tabular} & Ivano-Frankivsk \\
\hline 1 & 2 & \multicolumn{3}{|r|}{ 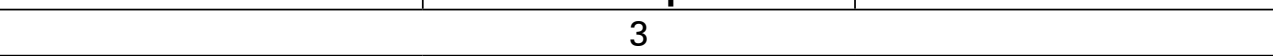 } \\
\hline 1 & $\begin{array}{l}\text { Developer of } \\
\text { the Program }\end{array}$ & $\begin{array}{l}\text { Department of } \\
\text { International Technical } \\
\text { Assistance and } \\
\text { International Cooperation } \\
\text { of the Regional State } \\
\text { Administration } \\
\end{array}$ & $\begin{array}{l}\text { Department of } \\
\text { International Cooperation } \\
\text { and Fundraising of } \\
\text { the Regional State } \\
\text { Administration }\end{array}$ & $\begin{array}{l}\text { Department of } \\
\text { International Cooperation } \\
\text { and Fundraising of } \\
\text { the Regional State } \\
\text { Administration }\end{array}$ \\
\hline 2 & $\begin{array}{l}\text { Terms of } \\
\text { execution }\end{array}$ & \multicolumn{2}{|l|}{$2018-2020$} & $2016-2020$ \\
\hline 3 & $\begin{array}{l}\text { Financing of } \\
\text { the Program } \\
\text { activities }\end{array}$ & $\begin{array}{l}\text { Regional budget and } \\
\text { other sources. } \\
\text { In } 2018 \text { - } 18400 \text { thousand } \\
\text { UAH (funds of the } \\
\text { regional budget); } \\
\text { in } 2019-2020 \text { - within } \\
\text { budget allocations }\end{array}$ & $\begin{array}{l}\text { Regional and district } \\
\text { budgets. } \\
\text { In 2018-2020-10315,0 } \\
\text { thousand UAH, } \\
\text { of them: } \\
\text { funds of the regional } \\
\text { budget - 10120,0 } \\
\text { thousand UAH; } \\
\text { funds of district budgets - } \\
\text { 195,0 thousand UAH. }\end{array}$ & $\begin{array}{l}\text { Regional budget and } \\
\text { other sources. } \\
\text { In } 2018-2020 \text { : } \\
\text { funds of the regional } \\
\text { budget - 1650,0 thousand } \\
\text { UAH; } \\
\text { funds of local budgets - } \\
\text { within budget allocations }\end{array}$ \\
\hline 4 & Reporting & $\begin{array}{l}\text { Every quarter, by the } \\
5 \text { th day of the next } \\
\text { month, information on } \\
\text { the implementation } \\
\text { of the Program by its } \\
\text { implementers is delivered } \\
\text { to the Department of } \\
\text { International Technical } \\
\text { Assistance and } \\
\text { International Cooperation, } \\
\text { which, in turn, informs } \\
\text { the Lviv Regional Council } \\
\text { in accordance with the } \\
\text { defined form by the 15th } \\
\text { day of the next month } \\
\text { after the reporting period. }\end{array}$ & $\begin{array}{l}\text { Twice a year, till January } \\
10 \text { and July } 10 \text {, executives } \\
\text { submit information on } \\
\text { the implementation } \\
\text { of the Program by } \\
\text { the Department of } \\
\text { International Cooperation } \\
\text { and Fundraising of } \\
\text { the Regional State } \\
\text { Administration for } \\
\text { generalization, which in } \\
\text { turn informs the regional } \\
\text { state administration and } \\
\text { the Ternopil Regional } \\
\text { Council annually till } \\
\text { January } 20 \text { and July } 20 .\end{array}$ & $\begin{array}{l}\text { Quarterly by the 10th } \\
\text { day of the month } \\
\text { following the reporting } \\
\text { period, in accordance } \\
\text { with paragraph } 5 \text { of } \\
\text { the Procedure for the } \\
\text { development of regional } \\
\text { target programs, } \\
\text { monitoring and reporting } \\
\text { on their implementation. }\end{array}$ \\
\hline
\end{tabular}


Ending of Table 1

\begin{tabular}{|c|c|c|}
\hline 1 & 2 & 3 \\
\hline 5 & $\begin{array}{l}\text { Expected } \\
\text { outcomes of } \\
\text { the program }\end{array}$ & 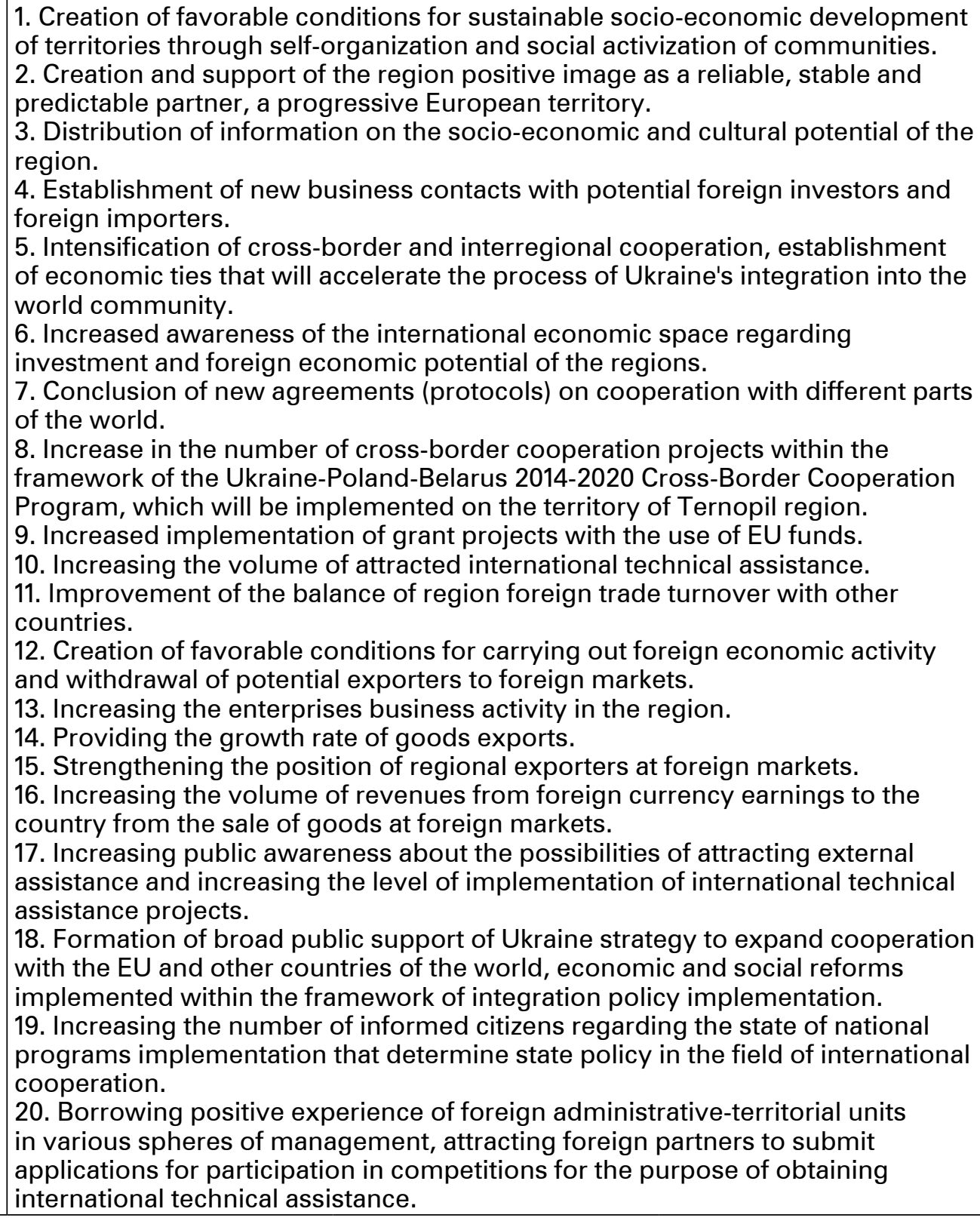 \\
\hline
\end{tabular}

Source: formed by the author on the basis of [1; 2; 3]

- insufficient level of interregional cooperation development in the field of economy;

- lack of statistical processing data on the state of interregional cooperation, which would allow to conduct comparative analysis of international interregional cooperation indicators and suggest ways to intensify cooperation in this area;

- inadequate level of specialists training, who carry out international cooperation at regional, city and district levels, in particular in the sphere of attraction of international technical assistance:

- the necessity for the development and modernization of the border infrastructure, provision of active cross-border and interregional contacts with neighbouring regions of foreign states with the aim to implement the state policy on European integration (Lviv region);

- low investment level (Ternopil region).

Thus, by outlining the problems that exist in area of regions international cooperation, and by summarizing the data provided in the Programs for Lviv, Ternopil and Ivano-Frankivsk regions, it's purpose can be identified as following: (1) ensuring the implementation of state policy in the field of international relations and cross-border cooperation; (2) implementation of a number of measures for cooperation with foreign Ukrainians; (3) the launch of new and development of existing links between regions with countries all over their 
$\frac{0}{\frac{0}{0}}$

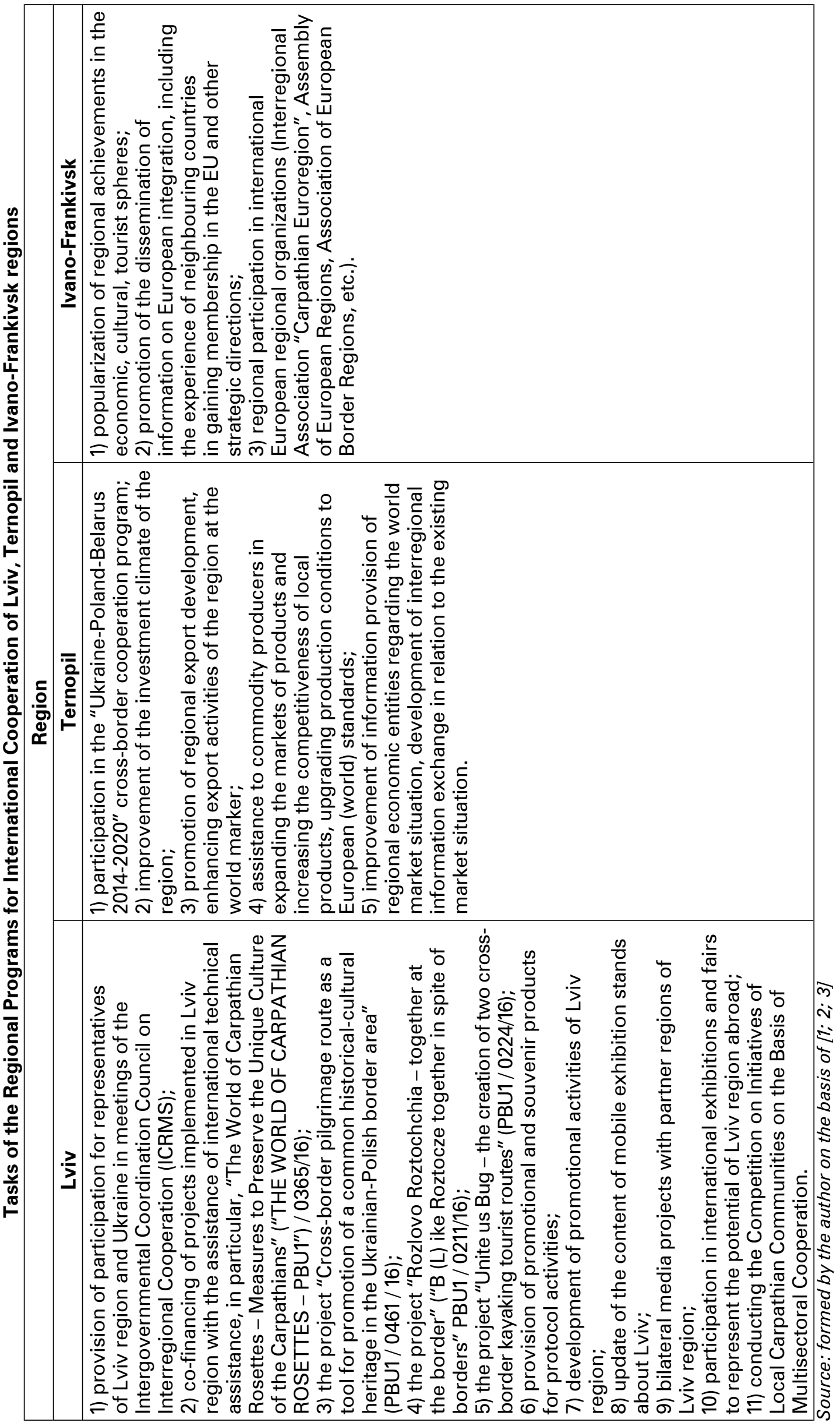


world and international organizations; (4) attraction of foreign investments, advanced technologies and best foreign management experience; (5) international cooperation in various spheres of public life $[1 ; 2 ; 3]$.

In order to realize main purpose of each Program, the following tasks, common to Lviv, Ternopil and Ivano-Frankivsk regions, were foreseen:

1) organization of meetings, conferences and negotiations with delegations and representatives of foreign states, international organizations;

2) intensification of cooperation within the framework of international, interregional organizations and Euroregions;

3) organization and holding of conferences, round tables, seminars on European and Euro-Atlantic integration;

4) development of existing and establishment of new ties with foreign countries, which have experience in attracting external assistance;

5) conducting training seminars and on-site consultations for NGOs and local authorities on the preparation of projects for recevieing international technical assistance;

6) organization of work on the dissemination of information about the region abroad in order to popularize the region and create an international positive image $[1 ; 2 ; 3]$.

In addition, Table 2 lists the tasks that are defined within each region in particular.

It is also identified that despite a number of joint tasks identified in the Regional Programs, each of them has different emphases, taking into account the specifics and urgent problems of the region.
For example, special attention of the Regional Program for International Cooperation of Lviv region is paid to co-financing of projects implemented with the attraction of international technical assistance, development of measures on region promotion at international markets, establishment of new and realization of existing ties with international organizations and foreign partners. At the same time, the main emphasis of the Ternopil Regional Program is on attracting investment in the region and expanding the markets for companies located there. The Program for Ivano-Frankivsk region also includes promotion of regional achievements in the economic, cultural, and tourist spheres in order to provide a positive image of the region.

In order to accomplish all objectives and achieve the goals set in the Programs, each of them also involves the implementation of a series of activities, the analysis of which is the subject of further research.

Conclusions. Thus, the development of international cooperation is one of the priority tasks for the Western region of Ukraine, which is highlighted in the Regional Programs for International Cooperation. The establishment of such cooperation will lead to a number of positive consequences, namely: improving the business climate and creating favorable conditions for investment in the economy of the western regions of Ukraine; increase of goods volumes turnover; development of small and medium enterprises economic activities; creation and operation of cross-border economic clusters; improvement and development of public infrastructure, etc.

\section{References:}

1. The Regional Target Program for the Development of International Cooperation of the Region for 2016-2020 [Electronic Resource] / Available at: http://www.if.gov.ua/files/uploads/program.pdf.

2. Regional program on international and cross-border cooperation of European integration for 2018-2020 [Electronic resource] / Available at: https://loda.gov.ua/tyr_prohramy.

3. The program for international cooperation of Ternopil region for 2018-2020 [Electronic
[Elon resource] / Available at: http://www.oda.te.gov.ua/data/upload/publication/main/ua/789/program spivrobyt2020.pdf. 